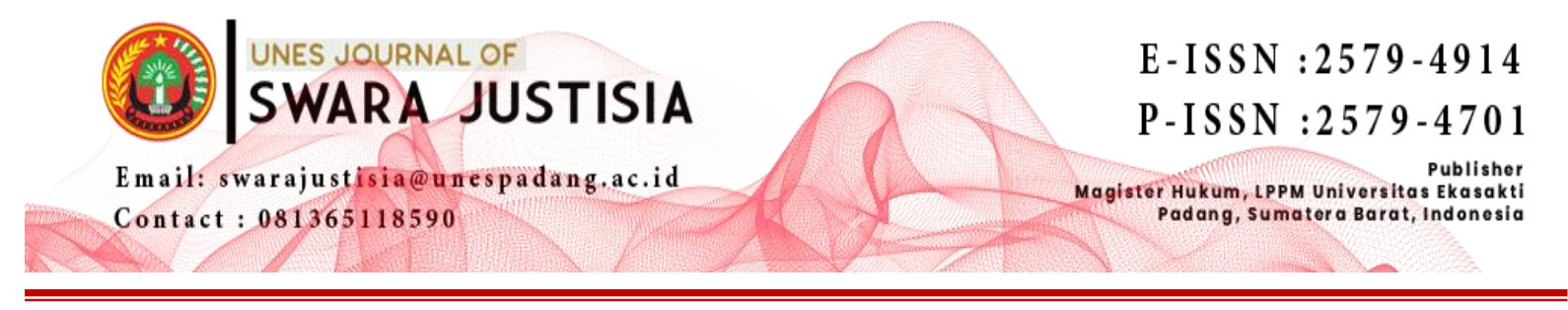

\title{
FUNGSI CRIME INDEX BAGI POLRES SOLOK KOTA DALAM PENANGGULANGAN TINDAK PIDANA
}

\author{
Aksalmadi \\ Program Magister Ilmu Hukum, Universitas Ekasakti, Padang, Indonesia \\ Email: aksal.madi71@gail.com
}

\begin{abstract}
The method for preparing the Crime Index by the Solok Kota Police is to compile indicators of the level of crime that has occurred, such as the total crime rate, the crime rate, and the crime clock. Is it based on the form of crime that often occurs, or is it based on the fluctuation in the number of crimes each month. The function of the Crime Index in Handling Crime by the Solok Kota Police is to carry out various activities to reduce the high number of crimes that occur by viewing and using criminal statistics and the criminal index created. By using the criminal index, it can be seen that the highest crime rate in the Solok Kota Police jurisdiction is the crime of theft with weight followed by motor vehicle theft. Efforts are being made to carry out various forms of police operations, one of which is the Singgalang / Jaran Singgalang pursuit operation. Besides conducting the Jaran Singgalang operation, Concentrated Operations were also carried out with the target of gambling. Operation Brush with the target of theft by weight and theft by force and Operation Tumpas Bandar with the target of trafficking narcotics.
\end{abstract}

Keywords: Crime Index, Crime, Prevention

\begin{abstract}
ABSTRAK
Metode penyusunan Indeks Kejahatan oleh Polres Solok Kota adalah dengan menyusun indikator-indikator tingkat kejahatan yang telah terjadi, seperti total angka kejahatan, angka kejahatan, dan jam kejahatan. Apakah berdasarkan bentuk kejahatan yang sering terjadi, atau berdasarkan fluktuasi jumlah kejahatan setiap bulannya. Fungsi Indeks Kejahatan Dalam Penanganan Tindak Pidana oleh Polres Solok Kota adalah melakukan berbagai kegiatan untuk menekan tingginya angka kejahatan yang terjadi dengan melihat dan menggunakan statistik kriminal dan indeks kriminal yang dibuat. Dengan menggunakan indeks kriminal dapat diketahui bahwa tingkat kriminalitas tertinggi di wilayah hukum Polres Solok Kota adalah tindak pidana pencurian dengan bobot disusul pencurian kendaraan bermotor. Berbagai bentuk operasi terus dilakukan kepolisian, salah satunya operasi pengejaran Singgalang/Jaran Singgalang. Selain melakukan Operasi Jaran Singgalang, Operasi Terpusat juga dilakukan dengan sasaran perjudian. Operasi Sikat dengan target pencurian berat dan pencurian dengan kekerasan dan Operasi Tumpas Bandar dengan target penyelundupan narkotika.
\end{abstract}

Kata Kunci: Indeks Kejahatan, Kejahatan, Pencegahan 


\section{PENDAHULUAN}

Di era kemajuan zaman seperti saat sekarang ini kita dituntut untuk hidup sesuai dengan perkembangan zaman. Perkembangan ilmu pengetahuan dan teknologi semakin canggih yang melahirkan alat-alat teknologi yang memudahkan setiap kegiatan. Hal-hal tersebut membuat kebutuhan hidup setiap individu meningkat khususnya dari segi ekonomi. Ini juga terjadi di Negara Indonesia dengan label negara yang masih berkembang, Indonesia harus mampu mengikuti kemajuan-kemajuan ini agar tidak tertinggal dari Negara lainnya. ${ }^{1}$

Keadaan ketidakmerataan taraf ekonomi yang ada di Indonesia ini membuat masyarakat kalangan bawah kesulitan untuk memenuhi tuntutan hidup sehingga menghalalkan berbagai cara untuk pemenuhannya seperti pencurian, penipuan, dan pembunuhan. Dilain sisi perkembangan teknologi yang memudahkan semua akses memungkinkan kita untuk membuka situs apa saja yang terkadang tidak seharusnya diakses. ${ }^{2}$ Hal ini merusak pola pikir individu yang mengakibatkan kejahatan seksualitas seperti pemerkosaan, pencabulan. Kejahatan perlu ditanggapi dan ditangani dengan serius.Suatu studi di Inggris oleh Steven Box memperlihatkan bahwa kejahatan dalam setiap saat cenderung meningkat, yang apabila dibiarkan menimbulkan kerusakan permanen bagi masyarakat, karena kejahatan lebih banyak dilakukan oleh orang-orang lebih muda, dan penganggur. ${ }^{3}$ Banyaknya perbuatan melanggar hukum khususnya perbuatan yang melanggar hukum pidana tersebut diatas membuat pihak berwenang harus bekerja keras untuk menegakkan hukum yang dilanggar tersebut khususnya kepolisian.

Tingginya angka kriminalitas ini dapat kita lihat dari statistik kriminal.Statistik adalah pengamatan massal dengan menggunakan angka-angka yang merupakan salah satu faktor pendorong perkembangan ilmu pengetahuan sosial pada abad ke-17. ${ }^{4}$ Dalam pengamatannya Quetelet melihat bahwa dalam kejahatan terdapat pola-pola yang setiap tahun selalu sama. Statistik kriminal adalah hasil pencatatan aparat penegak hukum (khususnya polisi) berdasarkan laporan korban dan masyarakat pada umumnya. ${ }^{5}$ Statistik kriminal berbentuk angka-angka yang menunjukkan jumlah kriminalitas yang tercatat, baik pada suatu waktu dan tempat tertentu. Aparat penegak hukum yang berperan penting disini adalah Kepolisian.Dimana polisi merupakan aparat penegak hukum pertama yang menyelidiki tentang terjadi atau tidaknya suatu kejahatan. ${ }^{6}$ Statistik kriminal kemudian dirangkum menjadi sebuah crime indek kejahatan.

Dalam menjalankan tugasnya salah satu wewenang polisi ialah menjalankan pusat informasi kriminal nasional sebagaimana tercantum dalam Pasal 15 ayat (1) huruf $j$ UndangUndang No. 2 Tahun 2002 Tentang Kepolisian Negara Republik Indonesia. Hal ini dipertegas dengan dikeluarkannya Peraturan Kepala Kepolisian Negara Republik Indonesia Nomor 15 Tahun 2010 tentang Penyelenggaraan Pusat Informasi Kriminal Nasional di Lingkungan Kepolisian Negara Republik Indonesia.

\footnotetext{
${ }^{1}$ Muhamad Ngafifi, Kemajuan Teknologi Dan Pola Hidup Manusia Dalam Perspektif Sosial Budaya, Jurnal Pembangunan Pendidikan: Fondasi dan Aplikasi, Volume 2, Nomor 1, 2014

2 Nanang Martono, Sosiologi perubahan sosial: perspektif klasik, modern, postmodern, dan postkolonial, PT. Raja Grafindo Persada, Jakarta, 2012, hlm 12

${ }^{3}$ Mien Rukmini, Aspek Hukum Pidana Dan Kriminologi, Alumni, Bandung, 2009, hlm. 95

${ }^{4}$ Topo Santoso dan Eva Achjani Zulfa, Kriminologi, Raja Grafindo Persada, Jakarta, 2012, hlm. 7

${ }_{6}^{5}$ J. Supranto M.A, Pengantar Statistik Bidang Hukum, Rineka Cipta, Jakarta, 1995, hlm. 51

${ }^{6}$ Hartono, Penyidikan \& Penegakan Hukum Pidana, Sinar Grafika, Jakarta, 2012,hlm. 21.
} 
Kepolisian Resort Solok Kota adalah institusi negara yang berada di bawah naungan Kepolisian Daerah Sumatera Barat yang memiliki tugas dan tanggung jawab untuk melayani masyarakat Kota Solok dalam proses penanganan berbagai macam permasalahan keamanan dan kriminalitas pada masyarakat Kota Solok. Reskrim Polres Solok Kota melakukan pencatatan atau statistic criminal yang kemudian disusun sebagai crime index. Adanya crime index ini, diharapkan dapat digunakan dalam menanggulangi kejahatan di kota Solok.

Berdasarkan latar belakang pemikiran di atas, maka permasalahan adalah dan fungsi metode penyusunan crime index oleh Polres Solok Kota

\section{METODE PENELITIAN}

Spesifikasi penelitian adalah deskriptif analitis, dengan metode pendekatan yuridis normative didukung oleh yuridis empiris. Jenis data yang digunakan adalah data sekunder. Data sekunder diperoleh dari studi dokumen dan studi kepustakaan. Data yang diperoleh kemudian dianalisa secara kualitatif.

\section{PEMBAHASAN}

\section{A. Metode Penyusunan Crime Index Oleh Polres Solok Kota}

Polri sebenarnya telah menyusun indikator tingkat kejahatan yang terjadi, seperti jumlah tindak pidana (crime total), angka tindak pidana (crime rate), dan selang waktu terjadinya tindak pidana (crime clock). Hanya saja, indikator-indikator tersebut disusun berdasarkan kasus yang dilaporkan ke polisi atau kasus yang tertangkap tangan. Ini berarti indikator-indikator tersebut belum mencakup peristiwa-peristiwa tindak pidana yang tidak dilaporkan/tidak tertangkap. Indikator indicator tersebut kemudian disusun dan dikelompokkan kembali ke dalam bentuk crime indexs. Mengingat budaya masyarakat Indonesia yang masih rendah dalam hal lapor-melapor, angka-angka ini diyakini masih jauh dari angka sesunguhnya.Sehubungan dengan itu, maka diperlukan alat ukur yang dapat mencerminkan situasi keamanan yang dirasakan masyarakat.

Tata cara dan teknik menyusun indeks memerlukan penguasaan teori mengindeks sebagai modal utama. Pelaksanaan sebaiknya berbuat dengan berlandaskan pada kebijaksanaan pemberi tugas. Sesudah orang mengetahui makna dan fungsi indeks, pelaksana yang lazim dikenal sebagai pengindeks (indexer) dalam proses kerjanya yang disebut mengindeks.

Penyusunan indek kriminal oleh Polres Solok Kota dilakukan dengan terlebih dahulu membuat statistik kriminal tentang kejahatan yang terjadi dalam satu semester pertahun. Sebelum dimulai melakukan indek, ada sesuatu persiapan untuk menyusun suatu indeks, adalah penting sekali untuk dua atau tiga kali membacateks dalam hal ini statistik kriminal yang telah dibuat. Ini berarti seorang yang akan melakukan pengindeksan berbuat untuk suatu studi awal dari apa yang akan dia tangani. Sesudah kebijaksanaan serta tujuan dilakukan indeks dipahami dengan benar, selanjutnya menyangkut kegiatan yang sifatnya teknis. Indeks apa yang harus disusun. Apakah berdasarkan bentuk kejahatan yang sering terjadi, ataukah berdasarkan naik turun jumlah kejahatan setiap bulannya. 
Petugas Pengindeksan selanjutnya bertugas menyusun indeks kejahatan yang cenderung terjadi dan menyusun perbandingan dengan indeks yang telah disusun sebelumnya. Masih banyak hal-hal yang perlu diperhatikan dalam proses mengindeks, tetapi tidak mungkin akan mengupas secara mendalam semua hal dalam melakukan indeks kejahatan. Indek kriminal harus dapat menunjukan kecenderungan atau gejala kejahatan yang terjadi pada suatu wilayah.

Pelaksanaan tugas Polri Polres Solok Kota seiring dengan perkembangan lingkungan global, regional dan nasional akan semakin berat dan kompleks. Tuntutan dan harapan masyarakat terhadap profesionalisme kinerja Polri Polres Solok Kota dan pelayanan di bidang kepolisian semakin tinggi, mengharuskan untuk menyusun berbagai upaya dan aksi konkrit yang efektif dalam mewujudkan keamanan di wilayah hukum Polres Solok Kota.

\section{B. Fungsi Crime Index Dalam Penanggulangan Tindak Pidana Oleh Polres Solok Kota}

Penanggulangan kejahatanmerupakan suatu kebijakan yang dapat diambil oleh pihak kepolisian yang berada diwilayah hukum Polres Solok Kota. Kebijakan penanggulangan kejahatan dilakukan agar tercapainya rasa aman dan damai di tengahtengah masyarakat dari para pelaku tindak pidana. Berdasarkan wawancara pada penelitian dalam melakukan penanggulangan kejahatan kepolisian yang berada di wilayah hukum Polres Solok kota telah melakukan berbagai kegiatan untuk menekan tingginya angka kejahatan yang terjadi dengan melihat dan mengunakan statistik kriminal dan indeks kriminal yang dibuat. Dengan menggunakan indeks kriminal tersebut maka terlihat pada angka kejahatan yang paling tinggi di wilayah hukum Polres Solok Kota adalah tindak pidana pencurian dengan pemberatan di lanjutkan dengan pencurian kendaraan bermotor.

Jenis Kriminalitas/Tindak Pidana yang mayoritas terjadi diwilayah Hukum Polres Solok Kota yakni :

(1) Pencurian dengan pemberatan (Curat)

(2) Pencurian Kendaraan bermotor (Curanmor).

(3) Curas (Pencurian dengan Kekerasan)

(4) Penganiayaan

(5) Penipuan

(6) Penggelapan

(7) Pengrusakan

(8) Perbuatan Tidak Menyenangkan

(9) Pemalsuan Surat

(10) Melarikan anak dibawah umur.

Kemudian faktor lain yang akan menjadi permasalahan dalam pelaksanaan tugas penaggulangan kejahatan dan peningkatan stanilitas keamanan di wilayah hukum Polres Solok Kota yaitu terjadinya konflik masalah tapal batas yang masih belum terselesaikan yang bersifat parmanen. Serta pertikaian pemilik tambang galian C di Paninggahan dengan warga Saniang Bakar, indikasi tersebut merupakan faktor dominan timbulnya gangguan kamtibmas, Permasalahan tersebut sudah berlarut-larut dan belum terselesaikan oleh Pemerintah Daerah/Nagari sehingga akan menjadi bom waktu terjadinya rusuh massal/perkelahian massa yang akan menimbulkan korban jiwa dan harta benda 
khususnya antara Nagari Muaro Pingai dan Nagari Saningbaka dimana dari permasalahan tapal batas ini sudah terjadi perkelahian massal 2 (dua) kali dan telah merengut korban jiwa dan harta benda. ${ }^{7}$

Pertikaian lain yang diduga akan terjadi adalah antara Nagari Saningbaka dengan Nagari Koto Sani, Nagari Sulit Air dengan Kota Sawah Lunto, Nagari Bukit Tandang dengan Nagari Bukit Bais dan Nagari Kinari, namun sampai saat ini belum ada jalan penyelesaiannya, hanya berupa janji yang sewaktu-waktu dapat berubah dari situasi aman menjadi perkelahian bahkan rusuh massal. Hal ini apabila tidak disikapi secara cermat oleh pihak yang berkompenten akan dapat mengganggu stabilitas kamtibmas di wilayah hukum Polres Solok Kota serta terhadap pelaksanaan tugas, baik lingkungan internal maupun eksternal.

Penanggulangan kejahatan secara preventif dilakukan oleh anggota Satuan Reserse Kriminal yang berada di wilayah hukum Polres Solok Kota. Kebijakan secara prepentif dilakukan dengan cara pengawasan terpadu secara patroli-patroli di tengah-tengah masyarakat. Patroli-patroli dilakukan didaerah-daerah yang rawan menjadi tempat pelaku kejahatan beraksi. Lokasi yang dipilih oleh pihak kepolisian yang berada di wilayah hukum Polres Solok Kota adalah tempat tempat yang rawan terjadi tindak pidana pencurian berdasarkan catatan statistic criminal yang telah disusun sebelumnya. Tempat yang dimaksud adalah seperti di kawasan perumahan warga, lokasi-lokasi parkir, daerah kos-kosan dan tempat-tempat lainnya.

Untuk secara tulisan penanggulangan kejahatan yang dilakukan oleh pihak kepolisian di wilayah hukum Polres Solok Kota adalah dengan cara memberikan himbauan secara tetulis. Himbauan secara tertulis yang dimaksud adalah dengan membuat spanduk-spanduk oleh pihak kepolisian agar masyarakat berhati-hati dan menghindari halhal yang dapat memancing pelaku tindak pidana pencurian dalam melakukan aksinya.Himbauan dalam bentuk spanduk di tempat- tempat keramaian seperti di tempat parkir, di daerah pasar, di daerah-daerah yang rawan untuk jenis tindak pidana pencurian kendaraan bermotor.

Dalam pemetaan daerah yang sering terjadi tindak pidana pencurian kendaraan bermotor di wilayah hukum Polres Solok Kota adalah di Daerah pasar raya. Pasar raya Solok adalah salah satu daerah yang menjadi sentral pusat perekonomian di Kota Solok. Pada Pasar raya Solok banyak terjadi tindak pidana pencurian kendaraan bermotor dan pencurian dengan pemberatan dikarenakan banyak terdapat lokasi pusat-pusat keramaian seperti pasar, pusat perbelanjaan, area wisata yang secara tidak langsung ramai pengunjung namun kurang pengamanan.

Pada objek wisata dan tempat parkir di lokasi keramaian tertentu yang rawan terjadi tindak pidana pencurian kendaraan bermotor dan pencurian dengan pemberatan, maka pihak kepolisian yang berada diwilayah hukum Polres Solok Kota menempatkan anggota kepolisian yang berpakaian preman. Penempatan polisi ini bertujuan untuk melindungi masyarakat dari berbagai bentuk tindak pidana yang mungin akan terjadi.

Berbagai bentuk penanggulangan kejahatan dengan secara preventif telah dilakukan secara aktif dan tanggap dalam melakukan pencegahan terhadap kasus kejahatan

\footnotetext{
${ }^{7}$ Wawancara dengan Wakil Kapolres Polres Solok Kota Pada tanggal 18 November 2020
} 
oleh pihak kepolisian yang berada di wilayah hukum Polres Solok Kota. Pihak kepolisian telah mengambil berbagai langkah kebijakan serta melaksanakan fungsi dan tugas dari kepolisian semaksimal mungkin.

Pihak kepolisian yang berada di wilayah hukum Polres Solok Kota melihat dan serta mengamati statistik kriminal yang ada serta mengambil suatu kesimpualan. Maka kepolisian merencanakan dan melakukan sebuah penanggulangan secara preventif. Pihak kepolisian memiliki suatu bentuk mekanisme sendiri dalam melakukan penanggulangan kejahatan. Berhasil atau tidaknya suatu mekasnisme yang di buat oleh pihak kepolisian yang berada di wilayah hukum Polres Solok Kota dalam melakukan penanggulangan kejahatan. Penanggulangan kejahatan yang dimaksud adalah penanggulangan tindak pidana pencurian kendaraan bermotor dan pencurian dengan pemberatan yang tertinggi angka indeksnya.

Dapat disadari faktor-faktor yang meyebabkan banyaknya kasus-kasus tindak pidana pencurian di wilayah hukum Polres Solok Kota, salah satunya faktor kesadaran dari masyarakat itu sendiri masyarakat diharapkan dapat memperkecil kemungkinan agar tidak menjadi korban.Dengan demikian maka kolerasi antara kepolisian dan masyarakat haruslah terjalin korelasi dengan baik agar mempersulit langkah-langkah pelaku dalam melakukan aksi kejahatanya.

Disamping melakukan Operasi Jaran Singgalang juga dilakukan Operasi Pekat dengan sasaran perjudian. Operasi Sikat dengan sasaran pencurian dengan pemberatan dan pencurian dengan kekerasan dan Operasi tumpas bandar dengan sasaran pengedaran narkotika. Penanggulangan kejahatan secara represif ini menitikberatkan pada sanksi bagi pelaku tindak pidana kejahatan.Sanksi yang diberikan adalah dalam bentuk sanksi pidana. Pemberian sanksi pidana ini bertujuan agar para pelaku menjadi jera untuk tidak mengualngi lagi aksi kejahatan yang dilakukanya. Pemberian sanksi pidana ini membuat pandangan masyarakat bahwa tindak pidana pencurian kendaraan bermotor tersebut adalah suatu perilaku yang dilarang oleh Undang- undang. Apabila melanggar aturan dari Undang-undang tersebut maka akan ada hukuman yang akan diberikan. Jadi masyarakat memiliki suatu rasa takut untuk melanggar aturan yang mengatur tentang tindak pidana pencurian tersebut.

Upaya dengan represif bisa dilakukan juga pada saat razia kendaraan bermotor yang di programkan oleh pihak kepolisian.Razia juga memiliki tujuan untuk melakukan pemeriksaan surat-surat kelengkapan kendaraan.Apabila polisi menemukan kecurigaan terhadap kendaraan yang digunakan oleh masyarakat dan diduga hasil dari pencurian kendaraan bermotor maka kepolisian melakukan penyelidikan lanjutan dari motor tersebut. Pihak kepolisian melakukan pengecekan kelengkapan surat-surat dari motor tersebut dan pihak kepolisian adan menyelidiki apakah motor tersebut motor curian atau motor yang dibeli dari hasil tindak pidana pencurian. Maka dari itu kepolisian akan menyita motor yang dalam operasi pihak kepolisian tidak memiliki surat-surat lengkap tanda kepemilikan motor.

Apabila suatu tindak pidana pencurian yang dilakukan pada malam hari maka itu termasuk dalam tindak pidana pencurian dengan pemberatan. Dimana tindak pidana pencurian dengan pemberatan diatur dalam pasal 363 KUHP. Pada jenis tindak pidana pencurian kendaraan bermotor dengan pemberatan adalah yang dalam melakukan tindak 
pidana pencurian pelaku dalam situasi dan keadaan tertentu. Pada kondisi malam hari pencurian dilakukan pada malam hari apabila dilakukan didalam rumah ataupun diluar rumah (perkarangan rumah), maka itu termasuk dalam tindak pidana pencuria dalam jenis pemberatan. Pada aksi pelaku yang juga dapat menjadi tindak pidana dengan pemberatan adalah pelaku melakukan aksi tindak pidana pencurian dengan cara bersama-sama atau lebih.

Penanggulangan kejahatan secara represif yang dilakukan oleh pihak kepolisian adalah dengan memberikan hukuman pada pelaku dengan seberat mungkin. Aparat kepolisan yang berada diwilayah hukum Polres Solok Kota selalu melakukan tindakantindakan represif dalam memproses pelaku tindak pidana pencurian. Pemberian sanksi ini juga haruslah sesuai dengan tindak pidana yang dilakukan oleh pelaku pencurian. Pemberian sanksi ini harus sesuai dengan peraturan perundang-undangan yang ada.Ini ditujukan agar dalam penangulangan kejahatan ini memberikan efek yang jera agar pelaku tidak mengulangi lagi tindak pidana yang pernah dilakukan oleh pelaku.

Upaya yang dilakukan oleh pihak kepolisian sudah cukup bagus dengan cara represif dimana pihak kepolisian menerapkan sanksi pidana bagi pelaku yang terbukti melakukan tindak pidana pencurian di wilayah hukum Polres Solok Kota. Namun juga masih banyak terjadi angka tindak pidana setiap bulan bahkan tahunya mengalami peningkatan. Disebabkan oleh faktor ekonomi dimana pelaku terpaksa melakukan aksi kejahatan pencurian disebabkan oleh faktor ekonomi. Dimana tekanan ekonomi membuat pelaku kejahatan melakukan apapun agar dapat memenuhi kebutuhan hidup dari pelaku. Seberapa baguspun sanksi yang diterapkan apabila masyarakat, kondisi ekonominya tidak mapan maka akan sangat mungkin pelaku akan selalu mengulangi kejahatan yang dilakukanya.

\section{KESIMPULAN}

Dengan mengunakan indeks kriminal tersebut maka terlihat pada angka kejahatan yang paling tinggi di wilayah hukum Polres Solok Kota adalah tindak pidana pencurian dengan pemberatan dilanjutkan dengan pencurian kendaraan bermotor. Jenis Kriminalitas/Tindak Pidana yang mayoritas terjadi diwilayah Hukum Polres Solok Kota berdasarkan crime indeks adalah Pencurian dengan pemberatan (Curat), Pencurian Kendaraan bermotor (Curanmor), Curas (Pencurian dengan Kekerasan), Penganiayaan, Penipuan, Penggelapan, Pengrusakan, Perbuatan Tidak Menyenangkan, Pemalsuan Surat, Melarikan anak dibawah umur. Usaha yang dilakukan adalah dengan mengadakan berbagai bentuk operasi Kepolisian salah satunya adalah Operasi pengejaran Singgalang/Jaran Singgalang. Disamping melakukan Operasi Jaran Singgalang juga dilakukan Operasi Pekat dengan sasaran perjudian.Operasi Sikat dengan sasaran pencurian dengan pemberatan dan pencurian dengan kekerasan dan Operasi tumpas bandar dengan sasaran pengedaran narkotika.

\section{DAFTAR PUSTAKA}

Muhamad Ngafifi, Kemajuan Teknologi Dan Pola Hidup Manusia Dalam Perspektif Sosial Budaya, Jurnal Pembangunan Pendidikan: Fondasi dan Aplikasi, Volume 2, Nomor 1, 2014 
Nanang Martono, Sosiologi perubahan sosial: perspektif klasik, modern, postmodern, dan postkolonial, PT. Raja Grafindo Persada, Jakarta, 2012

Mien Rukmini, Aspek Hukum Pidana Dan Kriminologi, Alumni, Bandung, 2009

Topo Santoso dan Eva Achjani Zulfa, Kriminologi, Raja Grafindo Persada, Jakarta, 2012

J. Supranto M.A, Pengantar Statistik Bidang Hukum, Rineka Cipta, Jakarta, 1995

Hartono, Penyidikan \& Penegakan Hukum Pidana, Sinar Grafika, Jakarta, 2012

Undang-Undang No. 2 Tahun 2002 Tentang Kepolisian Negara Republik Indonesia

Peraturan Kepala Kepolisian Negara Republik Indonesia Nomor 15 Tahun 2010 tentang Penyelenggaraan Pusat Informasi Kriminal Nasional di Lingkungan Kepolisian Negara Republik Indonesia. 